\title{
Association of intraoperative hypotension with acute kidney injury after liver resection surgery: an observational cohort study
}

Pingping Liao ${ }^{1+}$, Shuo Zhao ${ }^{2+}$, Lin Lyu $\mathrm{u}^{2,3^{*}+}$, Xuanlong $\mathrm{Yi}^{2}$, Xiangyu $\mathrm{Ji}^{2}$, Jian Sun ${ }^{2}$, Yanfang $\mathrm{Jia}^{2}$ and Zangong Zhou ${ }^{2^{*+}}$

\begin{abstract}
Background: Acute kidney injury (AKI) is a major complication following liver resection. The aim of this study was to determine the risk factors for AKI after hepatic resection and whether intraoperative hypotension (IOH) was related to AKl.

Methods: Adult patients ( $\geq 18$ years) undergoing liver resection between November 2017 and November 2019 at our hospital were retrospectively reviewed. AKI was defined as $\geq 50 \%$ increase in serum creatinine from baseline value within $48 \mathrm{~h}$ after surgery. $1 \mathrm{OH}$ was defined as the lowest absolute mean arterial pressure (MAP) $<65 \mathrm{mmHg}$ for more than 10 cumulative minutes during the surgery. Patients were divided into AKI group and non-AKI group, and were stratified by age $\geq 65$ years.

Results: 796 patients who met our inclusion and exclusion criteria were analyzed. After multivariable regression analysis, the $I O H(O R, 2.565 ; P=0.009)$ and age $\geq 65$ years $(O R, 2.463 ; P=0.008)$ were risk factors for AKI. The IOH $(O R$, $3.547 ; P=0.012)$ and received red blood cell $(O R, 3.032 ; P=0.036)$ were risk factors of $A K l$ in age $\geq 65$ years patients.

Conclusions: The $\mathrm{IOH}$ and age $\geq 65$ years were risk factors for postoperative AKI, and IOH was associated with AKI in age $\geq 65$ years patients following liver resection.
\end{abstract}

Keywords: Acute kidney injury, Intraoperative hypotension, Liver resection

\section{Background}

Postoperative acute kidney injury (AKI) is a major complication following liver resection, of which the incidence is reported approximately $8.7-15 \%[1,2]$. AKI in patients who have undergone liver resection is associated with prolonged hospital stay and hospital mortality [3] . As similar to AKI following other type of surgeries [4], AKI following

\footnotetext{
* Correspondence: alplvlin@126.com; 18661809837@163.com

†Pingping Liao and Shuo Zhao contributed equally to this work and should be regarded as co-first authors.

'Lin Lyu and Zangong Zhou contributed equally to this work and should be regarded as co-corresponding authors.

${ }^{2}$ Department of Anesthesiology, the Affiliated Hospital of Qingdao University, No.16 Jiangsu Road, Qingdao 266000, Shandong, China

Full list of author information is available at the end of the article
}

liver resection also increases the risk of mortality or developing chronic kidney disease (CKD) in the long term [5].

Many factors inducing renal cycles of ischemia and reperfusion during surgery lead to postoperative AKI, including high rates and volumes of blood product transfusion or infused fluid, use of vasopressors and blood loss etc. [6]. It is proposed that intraoperative hypotension $(\mathrm{IOH})$ resulting in disruption of renal perfusion may induce AKI [7]. As revealed by many studies, intraoperative decreased mean arterial pressure (MAP) was associated with postoperative AKI [8, 9].

Liver resection surgery is one of the most challenging abdominal surgical procedures. Characteristics of liver resection including clamping of portal vein, massive bleeding and low central venous pressure (CVP) technique induce

(c) The Author(s). 2020 Open Access This article is licensed under a Creative Commons Attribution 4.0 International License, which permits use, sharing, adaptation, distribution and reproduction in any medium or format, as long as you give appropriate credit to the original author(s) and the source, provide a link to the Creative Commons licence, and indicate if changes were made. The images or other third party material in this article are included in the article's Creative Commons licence, unless indicated otherwise in a credit line to the material. If material is not included in the article's Creative Commons licence and your intended use is not permitted by statutory regulation or exceeds the permitted use, you will need to obtain permission directly from the copyright holder. To view a copy of this licence, visit http://creativecommons.org/licenses/by/4.0/ The Creative Commons Public Domain Dedication waiver (http://creativecommons.org/publicdomain/zero/1.0/) applies to the data made available in this article, unless otherwise stated in a credit line to the data. 
low MAP during surgery [10-12]. Several studies have identified risk factors for postoperative AKI $[3,13]$. However, the association between $\mathrm{IOH}$ and postoperative AKI in liver resection surgery was unknown. Therefore, we conducted a single-center retrospective study to determine the risk factors for AKI after hepatic resection surgery and whether IOH was related to postoperative AKI.

\section{Methods}

\section{Study design and population}

This retrospective study was exempted from formal institutional review board of our hospital because these was no modified intervention or disclosure of personal information and the informed consent from patients was waived.

Adult patients ( $\geq 18$ years) undergoing liver resection between November 2017 and November 2019 at Affiliated Hospital of Qingdao University were retrospectively reviewed. The following procedures were excluded: pediatric patients $(<18$ years), patients with kidney disease or kidney surgery, liver resection combined with other surgery, liver radiofrequency ablation, liver resection for liver donation, nonmajor liver procedures (eg, biopsy and palliative operation), second surgery, post liver transplantation, trauma, metastases and patients without preoperative or postoperative creatinine.

\section{Data collection, definition and outcomes}

AKI was defined as $\geq 50 \%$ increase in serum creatinine $(\mathrm{sCr})$ from baseline value (preoperative) within $48 \mathrm{~h}$ after surgery based on Acute Kidney Injury Network (AKIN) creatinine criteria [14]. Urine output was not available in our postoperative cohort, so the AKIN urine output criteria was not used in this study. Demographics of patients, surgical and anesthetic information, laboratory values and postoperative data were manually abstracted from the electronic medical record database. Demographics of patients included: age, sex, body weight, American Society of Anesthesiologists (ASA) physical status, history of hypertension, diabetes, coronary heart disease (CHD), drugs use [ACEI/ARB (angiotensin converting enzyme inhibitors/angiotensin receptor blockers), NSAIDs (nonsteroidal anti-inflammatory drugs), diuretics] and hepatitis B. The surgical and anesthetic information were: preoperative MAP, laparoscope or not, major or minor resection, surgery duration, use of vasoactive inotropic agent, blood loss, urine volume, transfusion, nadir MAP, IOH or not, clamping of portal vein times and clamping of portal vein duration. The type of liver resection was classified as either minor resection (partial hepatectomy) or major resection (right, left, or trisectionsectomy). The MAP values were not directly measured, MAP was calculated as $(1 / 3 \times$ systolic blood pressure $+2 / 3 \times$ diastolic blood pressure) . Preinduction baseline MAP was obtained as the first valid value upon arrival to the operating room on the date of surgery as previous study defined [8]. IOH was defined as the lowest absolute MAP $<65 \mathrm{mmHg}$ for more than $10 \mathrm{cu}$ mulative minutes during the surgery [7]. The baseline $\mathrm{sCr}$ was defined as the preoperative $\mathrm{sCr}$ collected closest to the date of surgery within 1 month before surgery. The eGFR (estimated glomerular filtration rate) was calculated by Cockcroft-Gault Equation: eGFR $(\mathrm{ml} / \mathrm{min} / 1.73 \mathrm{~m} 2)=$ creatinine clearance $(\mathrm{Ccr}) \times 0.84 \times 1.73$ /body surface are $(\mathrm{BSA}) ; \quad \mathrm{Ccr}=[(140$-age $) \times$ weight $\times(0.85$ if female $)] /(72 \times$ $\mathrm{sCr}$ ). Postoperative $\mathrm{sCr}$ was the max $\mathrm{sCr}$ within $48 \mathrm{~h}$ after surgery, and postoperative aspartate aminotransferase (AST) and alanine aminotransferase (ALT) was abstracted the max value 7 days after surgery.

Intensive care unit (ICU) admission, hospital length of stay, re-operation and mortality were included in this study. Re-operation was defined as exploratory laparotomy because of biliary leakage and/or the presence of bleeding. Mortality was defined as any death occurring within 30 days following the date of surgery or in-hospital mortality.

\section{Statistical analysis}

All statistical analyses were performed using SPSS software (IBM Corp. Released 2012. IBM SPSS Statistics for Windows, Version 21.0. Armonk, NY: IBM Corp.). Categorical variables were expressed as frequencies with percentages and compared with chi-square test or Fisher's exact test as appropriate. Continuous variables were presented as mean \pm standard deviation or median with 25 th to 75 th percentiles, and were compared using the Student's t-test or Mann-Whitney-U test, where appropriate. Variables with a $p<0.1$ in univariate analysis or variables deemed important for clinical outcomes were further analyzed in multivariable regression model. Logistic regression analysis was used to identify risk factors associated with AKI after liver resection surgery. According to the result of logistic regression, age $\geq 65$ years and intraoperative hypotension were risk factors to AKI after liver resection. Therefore, we stratified the patients into age $<65$ years group and age $\geq 65$ years group according to other studies about elderly AKI [15-17]. Statistical significance was considered as a two-tailed $p<0.05$.

\section{Results}

Of 845 patients having liver surgery between November 2017 and November 2019 at Affiliated Hospital of Qingdao University, analysis included 796 patients who met our inclusion and exclusion criteria. The average age was 59 [52-65] years and male/female was 484/312. The rate of age $\geq 65$ years patients was $29.1 \%$. Indications for surgery were: hepatocellular carcinoma in 574 patients (72.1\%), cholangiocarcinoma in 115 patients (14.4\%), hepatolithiasis in 89 patients $(11.2 \%)$, hepatic hemangioma in 11 patients (1.4\%) and gallbladder cancer in 7 patients $(0.9 \%)$. The overall incidence of AKI was 5.0\% [AKIN1, 31(3.9\%); 
AKIN2, 6(0.7\%); AKIN3, 3(0.4\%)], and the incidence of AKI in age $\geq 65$ years group was $9.1 \%$. None of AKI patients needed continuous renal replacement therapy. The mortality was $0.4 \%$.

The demographics of patients between AKI and NonAKI group are shown in Table 1. Patients with AKI was older than patients without AKI $(p=0.003)$, and the rate of age $\geq 65$ years patients was higher in AKI group ( $p=$ 0.002). AST and ALT were higher in AKI group. Baseline $\mathrm{sCr}(p=0.056)$ and eGFR $(p=0.540)$ were not different between AKI group and Non-AKI group. The intraoperative characteristics and outcomes are presented in Table 2 between Non-AKI and AKI group. The intraoperative nadir MAP was lower in AKI group $(p=0.027)$, and the incidence of $\mathrm{IOH}$ was higher in AKI group during surgery $(p<0.001)$. The rate of norepinephrine use and the rate of received red blood cell and received plasma were high in AKI patients. The patients developed AKI suffered longer surgery duration $(p=0.001)$ and more blood loss $(p=$ $0.011)$ and needed more volumes of infused crystalloid $(p=0.006)$. The AKI group was associated with higher rate of ICU admission and longer hospital length of stay compared with the non-AKI group. As the result of univariate analysis, AST before surgery, $\mathrm{IOH}$, rate of age $\geq 65$ years, norepinephrine use, received red blood cell, received plasma, volumes of infused crystalloid, blood loss, urine volume and surgery duration were entered into multiple logistic regression analysis. The $\mathrm{IOH}$ and age $\geq 65$ years were risk factors for AKI after liver resection (Table 4).

In order to investigate whether elderly patients are sensitive to IOH for suffering AKI, we stratified the patients into age $<65$ years group and age $\geq 65$ years group. The rate of ASA class 3-4 was higher in AKI group in age $<$ 65 years patients $(p=0.032)$, and other characteristics before surgery was not different between AKI group and Non-AKI group in age $<65$ years patients (supplementary Table S1). There was no difference in preoperative characteristics between AKI group and Non-AKI group in age $\geq$ 65 years patients. AKI group suffered longer surgery duration compared with non-AKI group in age $<65$ years patients $(p=0.033)$. Although the rate of $\mathrm{IOH}$ was higher in AKI group compared with non-AKI group in age $<65$ years patients, there was no statistical difference between two groups $(p=0.070$, Table 3$)$. The rate of $\mathrm{IOH}$ was higher in AKI group compared with non-AKI group in

Table 1 Demographics of patients between Non-AKI group and AKI group

\begin{tabular}{|c|c|c|c|c|}
\hline Parameter & Non-AKI group $(n=756)$ & AKI group $(n=40)$ & $\mathbf{P}$ & Chi-squared \\
\hline Age (years), Median [25th to 75th P] & $59[51-65]$ & $65[56-68]$ & 0.003 & \\
\hline$\geq 65$ years, $n(\%)$ & $211(27.9 \%)$ & $21(52.5 \%)$ & 0.001 & 11.124 \\
\hline Weight (kg), Median [25th to 75th P] & $66.0[60.0-75.0]$ & $68.5[56.5-73.5]$ & 0.664 & \\
\hline Height (cm), Median [25th to 75th P] & $167.0[160.0-172.0]$ & $166.0[158.8-172.3]$ & 0.417 & \\
\hline Male, n(\%) & $460(60.8 \%)$ & $24(60.0 \%)$ & 0.915 & 0.011 \\
\hline Hypertension, n(\%) & $176(23.3 \%)$ & $14(35.0 \%)$ & 0.090 & 2.871 \\
\hline Diabetes, n(\%) & $102(13.5 \%)$ & $9(22.5 \%)$ & 0.109 & 2.569 \\
\hline CHD, $\mathrm{n}(\%)$ & $43(5.7 \%)$ & $5(12.5 \%)$ & 0.086 & \\
\hline Hepatitis B, n(\%) & $307(40.6 \%)$ & $12(30.0 \%)$ & 0.182 & 1.780 \\
\hline ACEI/ARB, n(\%) & $56(7.4 \%)$ & $6(15.0 \%)$ & 0.118 & \\
\hline Diuretics, n(\%) & $1(0.13 \%)$ & $0(0 \%)$ & 1.000 & \\
\hline NSAIDs, n(\%) & $24(3.2 \%)$ & $2(5.0 \%)$ & 0.380 & \\
\hline ASA class $1-2 /$ class 3-4 & $406 / 350$ & $16 / 24$ & 0.091 & 2.864 \\
\hline Major/Minor resection & $230 / 526$ & $14 / 26$ & 0.541 & 0.374 \\
\hline Laparoscope, n(\%) & 440 & 21 & 0.477 & 0.507 \\
\hline Preinduction baseline MAP (mmHg), Median [25th to 75th P] & $96.7[90.0-106.7]$ & $98.3[93.3-105.4]$ & 0.351 & \\
\hline \multicolumn{5}{|l|}{ Basic laboratory characteristics } \\
\hline AST (IU/L), Median [25th to 75th P] & $24[18-34]$ & $28[21-47]$ & 0.018 & \\
\hline ALT (IU/L), Median [25th to 75th P] & $24[16-41]$ & $30[20-50]$ & 0.041 & \\
\hline $\mathrm{sCr}(\mu \mathrm{mol} / \mathrm{L})$, Median [25th to 75th P] & $64.0[53.0-77.7]$ & $55.0[47.6-74.0]$ & 0.056 & \\
\hline eGFR $\left(\mathrm{ml} / \mathrm{min} / 1.73 \mathrm{~m}^{2}\right)$, Median [25th to 75 th P] & $82.2[67.3-100.4]$ & $87.9[68.5-105.1]$ & 0.540 & \\
\hline BUN ( $\mu \mathrm{mol} / \mathrm{L})$, Median [25th to 75th P] & $5.4[6.3-4.3]$ & $5.4[3.8-6.2]$ & 0.438 & \\
\hline
\end{tabular}

$A K I$ acute kidney injury, 25th to 75th $P$ 25th to 75th percentiles, $C H D$ coronary heart disease, $A C E I$ angiotensin converting enzyme inhibitors, $A R B$ angiotensin receptor blockers, NSAIDs non-steroidal anti-inflammatory drugs, ASA american society of anesthesiologists, MAP mean arterial pressure, AST aspartate aminotransferase, $A L T$ alanine aminotransferase, $s \mathrm{Cr}$ serum creatinine, eGFR estimated glomerular filtration rate, $B U N$ blood urea nitrogen 
Table 2 Intraoperative characteristics and outcomes between Non-AKI group and AKI group

\begin{tabular}{|c|c|c|c|c|}
\hline Parameter & Non-AKI group $(n=756)$ & AKI group $(n=40)$ & $\mathbf{P}$ & Chi-squared \\
\hline \multicolumn{5}{|l|}{ Intraoperative characteristics } \\
\hline Nadir MAP $(\mathrm{mmHg})$, mean \pm SD & $71.52 \pm 8.19$ & $66.92 \pm 12.33$ & 0.027 & \\
\hline Hypotension, n(\%) & $145(19.2 \%)$ & $19(47.5 \%)$ & $<0.001$ & 18.626 \\
\hline Norepinephrine use, n(\%) & $72(9.5 \%)$ & $9(22.5 \%)$ & 0.015 & \\
\hline Dopamine use, n(\%) & $16(2.1 \%)$ & $1(2.5 \%)$ & 0.588 & \\
\hline Milrinone use, n(\%) & $91(12.0 \%)$ & $6(15.0 \%)$ & 0.617 & \\
\hline Received red blood cell, n(\%) & $76(10.1 \%)$ & $11(27.5 \%)$ & 0.002 & \\
\hline Received plasma, n(\%) & $45(6.0 \%)$ & $9(22.5 \%)$ & 0.001 & \\
\hline Crystalloid (ml), Median [25th to 75th P] & 1500 [1000-1500] & 1500 [1000-2000] & 0.006 & \\
\hline Hydroxyethyl starch (ml), Median [25th to 75th P] & $500[500-500]$ & $500[500-1000]]$ & 0.211 & \\
\hline Blood loss (ml), Median [25th to 75th P] & 200 [100-300] & $300[100-775]$ & 0.011 & \\
\hline Urine volume (ml), Median [25th to 75th P] & $400[200-500]$ & $500[263-700]$ & 0.051 & \\
\hline Clamping of portal vein times (n), Median [25th to 75th P] & $1[1-2]$ & $2[1-2]$ & 0.609 & \\
\hline Clamping of portal vein duration (min), Median [25th to 75th P] & 20 [15-30] & 25 [17-30] & 0.736 & \\
\hline Surgery duration (hours), Median [25th to 75th P] & $3.0[2.5-4.0]$ & $4.0[3.1-4.5]$ & 0.001 & \\
\hline \multicolumn{5}{|l|}{ Postoperative laboratory characteristics } \\
\hline Peak AST (IU/L), Median [25th to 75th P] & $172.9[101.9-313.0]$ & $303.7[151.5-721.0]$ & 0.001 & \\
\hline Peak ALT (IU/L), Median [25th to 75th P] & $182[106-337]$ & $269[150-715]$ & 0.002 & \\
\hline Peak sCr ( $\mu \mathrm{mol} / \mathrm{L})$, Median [25th to 75th P] & $64.0[53.0-76.1]$ & 91.5 [74.4-138.5] & $<0.001$ & \\
\hline Minimum eGFR $\left(\mathrm{ml} / \mathrm{min} / 1.73 \mathrm{~m}^{2}\right)$, Median [25th to 75 th $\mathrm{P}$ ] & $81.2[68.1-100.6]$ & $53.1[38.4-69.7]$ & $<0.001$ & \\
\hline Peak BUN ( $\mu \mathrm{mol} / \mathrm{L})$, Median [25th to 75th P] & $5.7[4.8-6.8]$ & $7.3[5.5-10.0]$ & $<0.001$ & \\
\hline ICU admission, n(\%) & $46(6.1 \%)$ & $7(17.5 \%)$ & 0.013 & \\
\hline Hospital length of stay (days), Median [25th to 75th P] & $12[10-14]$ & 14 [10-20] & 0.027 & \\
\hline Re-operation, n(\%) & $4(0.5 \%)$ & $1(2.5 \%)$ & 0.228 & \\
\hline Mortality, n(\%) & $2(0.3 \%)$ & $1(2.5 \%)$ & 0.144 & \\
\hline
\end{tabular}

AKI acute kidney injury, MAP mean arterial pressure, 25th to 75th $P$ 25th to 75 th percentiles, AST aspartate aminotransferase, ALT alanine aminotransferase, $s C r$ serum creatinine, eGFR estimated glomerular filtration rate, BUN blood urea nitrogen, ICU intensive care unit

age $\geq 65$ years patients $(p=0.001$, Table 3$)$. The rate of norepinephrine use $(p=0.008)$, the rate of received red blood cell $(p=0.001)$ and the rate of received plasma $(p=0.001)$ were higher in AKI group in age $\geq 65$ years patients. The patients developed AKI suffered longer surgery duration $(p=0.030)$ and more blood loss $(p=0.016)$ in age $\geq 65$ years patients. The AKI group was associated with higher rate of ICU admission $(p=0.004)$ and longer hospital length of stay $(p=0.028)$ compared with the non-AKI group in age $\geq$ 65 years patients. According to the results of univariate analysis, ASA class, ALT before surgery, $\mathrm{IOH}$, volumes of infused crystalloid and surgery duration were entered into logistic regression analysis. ASA class 3-4 was a risk factor for AKI in age $<65$ years patients (Table 4 ). The AST before surgery, $\mathrm{IOH}$, norepinephrine use, volumes of infused crystalloid, the rate of received red blood cell and received plasma, blood loss and urine volume were further analyzed by multivariable logistic regression. The IOH $(p=0.012)$ and received red blood cell $(p=0.036)$ were associated with AKI in age $\geq 65$ years patients (Table 4 ).

\section{Discussion}

In this single-center cohort study, the total incidence of AKI after liver resection was $5.0 \%$, and the incidence of AKI in age $\geq 65$ years group was $9.1 \%$. The incidence of AKI is lower than results reported by other studies [1, 2]. The reason of low occurrence of AKI in our cohort is that the liver resection combined with other surgery, second surgery, post liver transplantation and metastases were excluded in this study. So the surgery in our study is less complicated than other studies $[15,18]$.

We found that the IOH was a risk factor for AKI after liver resection. Various definitions of intraoperative low MAP $(65-55 \mathrm{mmHg})$ which is related to AKI have been evaluated in the literature $[8,9]$. The incidence of AKI increased with the decrease of MAP during surgery [8]. Therefore, we chose upper limit (absolute MAP $<65$ $\mathrm{mmHg}$ during the surgery) as the threshold in this study [7]. Rhee et al. measured the renovascular reactivity to low MAP by a piglets experiment [19]. This study showed that renal blood flow decreased to 75,50 , and $25 \%$ of baseline 
Table 3 Intraoperative characteristics and outcomes between Non-AKI group and AKI group stratified by age $\geq 65$ years

\begin{tabular}{|c|c|c|c|c|c|c|c|c|}
\hline & \multicolumn{4}{|l|}{ Age $<65$ years } & \multicolumn{4}{|l|}{ Age $\geq 65$ years } \\
\hline & $\begin{array}{l}\text { Non-AKI group } \\
(n=545)\end{array}$ & $\begin{array}{l}\text { AKI group } \\
(n=19)\end{array}$ & $P$ & $\begin{array}{l}\text { Chi- } \\
\text { squared }\end{array}$ & $\begin{array}{l}\text { Non-AKI group } \\
(n=211)\end{array}$ & $\begin{array}{l}\text { AKI group } \\
(n=21)\end{array}$ & $P$ & $\begin{array}{l}\text { Chi- } \\
\text { squared }\end{array}$ \\
\hline \multicolumn{9}{|l|}{ Intraoperative characteristics } \\
\hline $\begin{array}{l}\text { Nadir MAP }(\mathrm{mmHg}) \\
\text { mean } \pm \text { SD }\end{array}$ & $71.83 \pm 8.24$ & $69.65 \pm 12.41$ & 0.469 & & $70.72 \pm 8.02$ & $64.59 \pm 12.06$ & 0.033 & \\
\hline Hypotension, n(\%) & $102(18.7 \%)$ & $7(36.8 \%)$ & 0.070 & & $43(20.4 \%)$ & $12(57.1 \%)$ & 0.001 & \\
\hline Norepinephrine use, n(\%) & $50(9.2 \%)$ & $2(10.5 \%)$ & 0.692 & & $22(10.4 \%)$ & $7(33.3 \%)$ & 0.008 & \\
\hline Dopamine use, n(\%) & $14(2.6 \%)$ & $0(0)$ & 1.000 & & $2(0.9 \%)$ & $1(4.8 \%)$ & 0.249 & \\
\hline Milrinone use, n(\%) & $56(10.3 \%)$ & $3(15.8 \%)$ & 0.437 & & $35(16.6 \%)$ & $3(14.3 \%)$ & 1.000 & \\
\hline Received red blood cell, n(\%) & 49 (9.0\%) & $2(10.5 \%)$ & 0.686 & & $27(12.8 \%)$ & $9(42.9 \%)$ & 0.001 & \\
\hline Received plasma, n(\%) & $30(5.5 \%)$ & $2(10.5 \%)$ & 0.294 & & $15(7.1 \%)$ & $7(33.3 \%)$ & 0.001 & \\
\hline $\begin{array}{l}\text { Crystalloid }(\mathrm{ml}) \text {, Median } \\
\text { [25th to } 75 \text { th P] }\end{array}$ & $\begin{array}{l}1400[1000- \\
1500]\end{array}$ & $\begin{array}{l}1500[1000- \\
2000]\end{array}$ & 0.057 & & $\begin{array}{l}1500[1000- \\
1500]\end{array}$ & $\begin{array}{l}1500[1000- \\
2325]\end{array}$ & 0.061 & \\
\hline $\begin{array}{l}\text { Hydroxyethyl starch }(\mathrm{ml}) \text {, } \\
\text { Median [25th to } 75 \text { th } \mathrm{P}]\end{array}$ & 500 [500-500] & $500[500-500]$ & 0.950 & & $500[500-563]$ & 500 [500-1000] & 0.119 & \\
\hline $\begin{array}{l}\text { Blood loss }(\mathrm{mll}) \text {, Median } \\
{[25 \text { th to } 75 \text { th P] }}\end{array}$ & 200 [100-300] & $200[50-400]$ & 0.357 & & 200 [100-325] & 500 [150-1150]] & 0.016 & \\
\hline $\begin{array}{l}\text { Urine volume }(\mathrm{ml}) \text {, Median } \\
\text { [25th to } 75 \text { th P] }\end{array}$ & $300[200-500]$ & $400[250-600]$ & 0.468 & & $400[200-600]$ & $500[250-800]$ & 0.068 & \\
\hline $\begin{array}{l}\text { Clamping of portal vein } \\
\text { times (n), Median } \\
{[25 \text { th to } 75 \text { th } P]}\end{array}$ & $1[1-2]$ & $1.5[1-2]$ & 0.933 & & $1[1-2]$ & $2[1-2.5]$ & 0.297 & \\
\hline $\begin{array}{l}\text { Clamping of portal vein } \\
\text { duration (min), Median } \\
\text { [25th to } 75 \text { th P] }\end{array}$ & 25 [15-30] & $25[16-29]$ & 0.959 & & $20[15-30]$ & $20[17-43]$ & 0.586 & \\
\hline $\begin{array}{l}\text { Surgery duration (hours), } \\
\text { Median [25th to } 75 \text { th P] }\end{array}$ & $3.0[2.5-4.0]$ & $4.0[3.0-4.5]$ & 0.033 & & $3.5[2.5-4.5]$ & $4.0[3.3-5.0]$ & 0.030 & \\
\hline \multicolumn{9}{|l|}{ Postoperative laboratory characteristics } \\
\hline $\begin{array}{l}\text { Peak AST (IU/L), Median } \\
\text { [25th to } 75 \text { th P] }\end{array}$ & 174 [101-331] & 310 [162-718] & 0.066 & & 164 [103-264] & 298 [140-800] & 0.005 & \\
\hline $\begin{array}{l}\text { Peak ALT (IU/L), Median } \\
{[25 \text { th to } 75 \text { th P] }}\end{array}$ & $192[113-371]$ & $272[181-600]$ & 0.031 & & 155 [96-282] & 266 [128-1052] & 0.008 & \\
\hline $\begin{array}{l}\text { Peak sCr }(\mu \mathrm{mol} / \mathrm{L}), \text { Median } \\
{[25 \text { th to } 75 \text { th P] }}\end{array}$ & $62.4[51.7-75.0]$ & $90.0[67.2-141.0]$ & $\begin{array}{l}< \\
0.001\end{array}$ & & $66.0[56-80.0]$ & $95.0[74.8-136.5]$ & $\begin{array}{l}< \\
0.001\end{array}$ & \\
\hline $\begin{array}{l}\text { Minimum eGFR }\left(\mathrm{ml} / \mathrm{min} / 1.73 \mathrm{~m}^{2}\right) \\
\text { Median }[25 \text { th to } 75 \text { th } \mathrm{P}] \text { or } \\
\text { mean } \pm \mathrm{SD}\end{array}$ & 89.7 [74.5-108.1] & $62.3[42.2-72.4]$ & $\begin{array}{l}< \\
0.001\end{array}$ & & $68.67 \pm 17.66$ & $46.59 \pm 18.08$ & $\begin{array}{l}< \\
0.001\end{array}$ & \\
\hline $\begin{array}{l}\text { Peak BUN }(\mu \mathrm{mol} / \mathrm{L}), \\
\text { Median }[25 \text { th to } 75 \text { th P] }\end{array}$ & $5.5[4.6-6.5]$ & $6.3[5.2-8.8]$ & 0.009 & & $6.4[5.3-7.5]$ & $7.4[5.6-13.1]$ & 0.029 & \\
\hline ICU admission, n(\%) & $27(5.0 \%)$ & $0(0)$ & 1.000 & & $19(9.0 \%)$ & $7(33.3 \%)$ & 0.004 & \\
\hline $\begin{array}{l}\text { Hospital length of stay (days), } \\
\text { Median [25th to } 75 \text { th P] }\end{array}$ & $11[9-14]$ & 13 [9-15] & 0.505 & & 13 [10-15] & $16[11-26]$ & 0.028 & \\
\hline Re-operation, n(\%) & $3(0.6 \%)$ & $1(5.3 \%)$ & 0.128 & & $1(0.5 \%)$ & $0(0)$ & 1.000 & \\
\hline Mortality, n(\%) & $1(0.2 \%)$ & $0(0)$ & 1.000 & & $1(0.5 \%)$ & $1(4.8 \%)$ & 0.173 & \\
\hline
\end{tabular}

AKI acute kidney injury, MAP mean arterial pressure, SD standard deviation, 25th to 75th $P 25$ th to 75 th percentiles, AST aspartate aminotransferase, $A L T$ alanine aminotransferase, $\mathrm{sCr}$ serum creatinine, eGFR estimated glomerular filtration rate, BUN blood urea nitrogen, ICU intensive care unit

when MAP decreased to 60,45 , and $40 \mathrm{mmHg}$. Blood loss remains a major complication in liver resection surgery [10], which is the main reason of low MAP during surgery. AKI patients suffered more blood loss in our study, which is consistent with other study [20]. To avoid hypotension during surgery, blood transfusion, volumes of infused fluid and frequency use of norepinephrine were employed to maintain an acceptable level of MAP. These techniques were used more in AKI group in this study. The intraoperative red blood cell transfusion has been proved to be a risk 
Table 4 Logistic regression model for risk factors of AKI

\begin{tabular}{llllll}
\hline Risk factors & $\boldsymbol{\beta}$ & SE & Odds ratio & $\mathbf{9 5 \%} \mathbf{C l}$ & $\mathbf{P}$ \\
\hline $\mathrm{IOH}$ & 0.942 & 0.358 & 2.565 & $1.271-5.177$ & 0.009 \\
Age $\geq$ 65 years & 0.901 & 0.340 & 2.463 & $1.264-4.800$ & 0.008 \\
& Age $<65$ years & & \\
ASA class 3-4 & -1.251 & 0.630 & 0.372 & $0.083-0.983$ & 0.047 \\
& Age $\geq 65$ years & & \\
$\mathrm{IOH}$ & 1.266 & 0.503 & 3.547 & $1.323-9.505$ & 0.012 \\
Received red blood cell & 1.109 & 0.530 & 3.032 & $1.073-8.568$ & 0.036
\end{tabular}

AKI acute kidney injury, IOH intraoperative hypotension, ASA American Society of Anesthesiologists, SE standard error, $\mathrm{Cl}$ confidence interval

factor of AKI after liver resection surgery [3]. Many biochemical and biomechanical changes associated with erythrocytes storage include depletion of ATP and 2,3-DPG, membrane phospholipid vessiculation and loss, lipid peroxidation of red blood cell membrane. These changes cause impaired oxygen unloading from hemoglobin and loss of deformability. The loss of deformability leads to obstructed capillaries and then causes impairment of oxygen delivery to tissues [21]. Use of norepinephrine may potentially leads to decrease in renal blood flow and renal oxygen delivery. This result has been proved by animal experiments and healthy volunteers [22, 23]. However, restoration of MAP from 60 to $75 \mathrm{mmHg}$ induced by norepinephrine increases renal oxygen delivery, glomerular filtration rate and renal oxygenation in post-cardiac surgery AKI patients [24]. Therefore, low MAP corrected by norepinephrine when MAP is below $60 \mathrm{mmHg}$ may improve renal perfusion in liver resection surgery.

In this study, mean age was higher in AKI group, and the incidence of age $\geq 65$ years was identified as a risk factor for AKI following liver resection. Although Dedinska et al., [15] found that the incidence of AKI was higher in elderly patients following liver resection surgery, the age was not an independent risk factor for AKI. This may be explained by the different inclusion. In the Dedinska et al., [15] study, colorectal carcinoma with metastases in the liver were more frequent in the group of patients older than 65 years and the histological identification of colorectal carcinoma metastases was a risk factor for AKI. Therefore, the patients older than 65 years may be a risk factor when colorectal carcinoma with metastases was excluded. It has been suggested in a previous study that glomerular filtration rate and autoregulation of renal blood flow decrease with the ageing [25]. Hence this physiologic decline in renal function may predispose the elderly patients to the subsequent development of AKI. In addition, elderly patients often have comorbidities before surgery such as hypertension, cardiovascular disease and diabetes mellitus. These comorbidities make elderly patients susceptible to AKI [26].

In order to investigate the relationship between $\mathrm{IOH}$ and AKI in elderly patients, patients were stratified into age $<$
65 years group and age $\geq 65$ years group. We found the $\mathrm{IOH}$ was a risk factor of AKI in elderly patients, while $\mathrm{IOH}$ was not a risk factor for AKI in patients with age $<65$ years. It is more difficult to manage perioperative hemodynamic instability in elderly patients than that in young patients [27]. The GFR (glomerular filtration rate) was associated with left ventricular function and the elderly patients with impaired left ventricular function are susceptive to AKI [28]. In addition, the aging kidney diminishes responsiveness to vasodilators and increases sensitivity to vasoconstrictors [29], which enhance renal ischemia. Fluid therapy is employed to correct hypotension during surgery. However, fluid overload increases burden on elderly renal causing by decreased number of glomerular and tubular volume in aging renal [30], and fluid overload increases AKI severity [31]. A recent review suggested that the haemodynamic management of the elderly patients with surgery should focus on avoiding hypotension and high central venous pressures (CVP) during surgery to decrease risk of AKI [32]. In this study, the rate of received red blood cell and received plasma were higher in elderly patients with AKI. Several animal experiments have shown that aging rats are more susceptible to renal ischemia-reperfusion injury [33, 34]. A sudden substantial blood loss is often associated with a period of decreased MAP during surgery, which causes renal hypoperfusion. Meanwhile, the treatment with overload fluid infusion, blood transfusion and vasopressors to elevate MAP results in renal injury in elderly patients. That may explain that $\mathrm{IOH}$ is a risk factor of AKI in elderly patients. Therefore, patients especially elderly patients with surgery need perioperative hemodynamic optimization to decrease risk of renal impairment [35].

Our results are broadly consistent with the results of previous studies that postoperative AKI is associated with significantly increased rates of ICU admission and hospital length of stay in patients with liver surgery $[3,15]$. Other studies have reported that short-term mortality is higher in AKI patients after liver resection [18].

There are several limitations to the present study. First, this was a retrospective single center study, so it had the inherent potential for bias. Second, the effect of low CVP strategy or persistent high level of CVP on the occurrence of AKI was not evaluated, since few CVP was continuously monitored and recorded during the surgery. Third, the $\mathrm{IOH}$ was not stratified by intraoperative MAP value and low MAP duration because of small sample size. Finally, whether $\mathrm{IOH}$ is associated with CKD in AKI patients after liver resection surgery should be studied by further research.

\section{Conclusions}

$\mathrm{IOH}$ and age $\geq 65$ years were risk factors for AKI after liver resection, and $\mathrm{IOH}$ was associated with AKI in age $\geq 65$ years patients following liver resection. 


\section{Supplementary information}

Supplementary information accompanies this paper at https://doi.org/10. 1186/s12882-020-02109-9.

Additional file 1: Supplementary Table. Table S1. Demographics of patients between Non-AKI group and AKI group stratified by age $\geq 65$ years. AKI, acute kidney injury; 25th to 75th $\mathrm{P}$, 25th to 75th percentiles; $\mathrm{SD}$, standard deviation; CHD, coronary heart disease; $\mathrm{ACEl}$, angiotensin converting enzyme inhibitors; ARB, angiotensin receptor blockers; NSAIDs, non-steroidal anti-inflammatory drugs; ASA, american society of anesthesiologists; MAP, mean arterial pressure; AST, aspartate aminotransferase; $\mathrm{ALT}$, alanine aminotransferase; $\mathrm{sCr}$, serum creatinine; eGFR, estimated glomerular filtration rate; BUN, blood urea nitrogen

\section{Abbreviations}

AKI: Acute kidney injury; CKD: Chronic kidney disease; IOH: Intraoperative hypotension; MAP: Mean arterial pressure; CVP: Central venous pressure; sCr: Serum creatinine; AKIN: Acute Kidney Injury Network; ASA: American Society of Anesthesiologists; CHD: Coronary heart disease; AST: Aspartate aminotransferase; ALT: Alanine aminotransferase; ICU: Intensive care unit; ACEl: Angiotensin converting enzyme inhibitors; ARB: Angiotensin receptor blockers; NSAIDs: Non-steroidal anti-inflammatory drugs; eGFR: Estimated glomerular filtration rate

\section{Acknowledgements}

Not applicable.

\section{Authors' contributions}

PPL, SZ, LL and ZGZ contributed to study conception and design; JS, YFJ and $\mathrm{LL}$ collected the data; XLY and XYJ analyzed and interpreted the data; ZGZ reviewed the statistical methods and analysis; PPL and SZ wrote the manuscript; LL and ZGZ made the critical revision of the article. All authors read and approved the final manuscript.

\section{Funding}

This work was supported by the National Natural Science Foundation of China (No. 81902001) in data collection, analysis and writing manuscript.

\section{Availability of data and materials}

The datasets used and analysed during the current study are available from the corresponding author on reasonable request

\section{Ethics approval and consent to participate}

This retrospective study was exempted from the Institutional Review Board of the Ethics Committee of the Affiliated Hospital of Qingdao University because these was no modified intervention or disclosure of personal information and the informed consent from patients was waived.

\section{Consent for publication}

Not applicable.

\section{Competing interests}

The authors declare that they have no competing interests.

\section{Author details}

${ }^{1}$ Department of Geriatric Medicine, the Affiliated Hospital of Qingdao University, Qingdao 266000, Shandong, China. ${ }^{2}$ Department of Anesthesiology, the Affiliated Hospital of Qingdao University, No.16 Jiangsu Road, Qingdao 266000, Shandong, China. Department of Anesthesiology, the Affiliated Hospital of Qingdao University, No.59 Haier Road, Qingdao 266000, Shandong, China.

Received: 18 July 2020 Accepted: 14 October 2020

Published online: 02 November 2020

\section{References}

1. Zhou X, Wang L, Wang G, Cheng X, Hu S, Ke W, Li M, Zhang Y, Song Z, Zheng Q. A new plasma biomarker enhance the clinical prediction of postoperative acute kidney injury in patients with hepatocellular carcinoma. Clin Chim Acta. 2017;475:128-36.
2. Slankamenac K, Breitenstein S, Held U, Beck-Schimmer B, Puhan MA, Clavien PA. Development and validation of a prediction score for postoperative acute renal failure following liver resection. Ann Surg. 2009;250(5):720-8.

3. Tomozawa A, Ishikawa S, Shiota N, Cholvisudhi P, Makita K. Perioperative risk factors for acute kidney injury after liver resection surgery: an historical cohort study. Can J Anaesth. 2015;62(7):753-61.

4. Palant CE, Amdur RL, Chawla LS. Long-term consequences of acute kidney injury in the perioperative setting. Curr Opin Anaesthesiol. 2017;30(1):100-4.

5. Ishikawa S, Tanaka M, Maruyama F, Fukagawa A, Shiota N, Matsumura S, Makita K. Effects of acute kidney injury after liver resection on long-term outcomes. Korean J Anesthesiol. 2017:70(5):527-34.

6. O'Neal JB, Shaw AD, Billings FT. Acute kidney injury following cardiac surgery: current understanding and future directions. Crit Care. 2016;20(1):187.

7. Wesselink EM, Kappen TH, Torn HM, Slooter AJC, van Klei WA. Intraoperative hypotension and the risk of postoperative adverse outcomes: a systematic review. Br J Anaesth. 2018;121(4):706-21.

8. Mathis MR, Naik BI, Freundlich RE, Shanks AM, Heung M, Kim M, Burns ML, Colquhoun DA, Rangrass G, Janda A, et al. Preoperative risk and the association between hypotension and postoperative acute kidney injury. Anesthesiology. 2020;132(3):461-75.

9. Sun LY, Wijeysundera DN, Tait GA, Beattie WS. Association of intraoperative hypotension with acute kidney injury after elective noncardiac surgery. Anesthesiology. 2015;123(3):515-23.

10. Shirabe K, Kajiyama K, Harimoto N, Tsujita E, Wakiyama S, Maehara Y. Risk factors for massive bleeding during major hepatectomy. World J Surg. 2010; 34(7):1555-62.

11. Hughes MJ, Ventham NT, Harrison EM, Wigmore SJ. Central venous pressure and liver resection: a systematic review and meta-analysis. HPB. 2015;17(10):863-71.

12. Correa-Gallego C, Berman A, Denis SC, Langdon-Embry L, O'Connor D, Arslan-Carlon V, Kingham TP, D'Angelica MI, Allen PJ, Fong Y, et al. Renal function after low central venous pressure-assisted liver resection: assessment of 2116 cases. HPB. 2015;17(3):258-64.

13. Kim M, Kiran RP, Li G. Acute kidney injury after hepatectomy can be reasonably predicted after surgery. J Hepatobiliary Pancreatic Sci. 2019;26(4):144-53.

14. Thomas ME, Blaine C, Dawnay A, Devonald MA, Ftouh S, Laing C, Latchem S, Lewington A, Milford DV, Ostermann M. The definition of acute kidney injury and its use in practice. Kidney Int. 2015;87(1):62-73.

15. Dedinska I, Mikolajcik P, Skalova P, Mokan M, Laca L. Acute kidney injury after liver resection in elderly patients. BMC Nephrol. 2019;20(1):272.

16. Chao CT, Lin YF, Tsai HB, Wu VC, Ko WJ. Acute kidney injury network staging in geriatric postoperative acute kidney injury patients: shortcomings and improvements. J Am Coll Surg. 2013;217(2):240-50.

17. Chao CT, Wu VC, Lai CF, Shiao CC, Huang TM, Wu PC, Tsai IJ, Hou CC, Wang WJ, Tsai HB, et al. Advanced age affects the outcome-predictive power of RIFLE classification in geriatric patients with acute kidney injury. Kidney Int. 2012:82(8):920-7.

18. Garnier J, Faucher M, Marchese U, Meillat H, Mokart D, Ewald J, Delpero JR, Turrini $O$. Severe acute kidney injury following major liver resection without portal clamping: incidence, risk factors, and impact on short-term outcomes. HPB. 2018;20(9):865-71.

19. Rhee CJ, Kibler KK, Easley RB, Andropoulos DB, Czosnyka M, Smielewski P Brady KM. Renovascular reactivity measured by near-infrared spectroscopy. J Appl Physiol. 2012;113(2):307-14.

20. Hallqvist L, Granath F, Huldt E, Bell M. Intraoperative hypotension is associated with acute kidney injury in noncardiac surgery: an observational study. Eur J Anaesthesiol. 2018;35(4):273-9.

21. Tinmouth A, Fergusson D, Yee IC, Hebert PC, Investigators A. Canadian critical care trials $\mathrm{G}$ : clinical consequences of red cell storage in the critically ill. Transfusion. 2006:46(11):2014-27.

22. Schrier RW, Arnold PE, Gordon JA, Burke TJ. Protection of mitochondrial function by mannitol in ischemic acute renal failure. Am J Phys. 1984;247(2 Pt 2):F365-9.

23. Hoogenberg K, Smit AJ, Girbes AR. Effects of low-dose dopamine on renal and systemic hemodynamics during incremental norepinephrine infusion in healthy volunteers. Crit Care Med. 1998:26(2):260-5.

24. Redfors B, Bragadottir G, Sellgren J, Sward K, Ricksten SE. Effects of norepinephrine on renal perfusion, filtration and oxygenation in vasodilatory shock and acute kidney injury. Intensive Care Med. 2011;37(1):60-7.

25. Raman M, Middleton RJ, Kalra PA, Green D. Estimating renal function in old people: an in-depth review. Int Urol Nephrol. 2017;49(11):1979-88.

26. James MT, Grams ME, Woodward M, Elley CR, Green JA, Wheeler DC, de Jong P, Gansevoort RT, Levey AS, Warnock DG, et al. A meta-analysis of the 
Association of Estimated GFR, albuminuria, diabetes mellitus, and hypertension with acute kidney injury. Am J Kidney Dis. 2015;66(4):602-12.

27. Kozarek K, Sanders RD, Head D. Perioperative blood pressure in the elderly. Curr Opin Anaesthesiol. 2020;33(1):122-0.

28. Nerpin E, Ingelsson E, Riserus U, Sundstrom J, Andren B, Jobs E, Larsson A, Lars L, Arnlov J. The association between glomerular filtration rate and left ventricular function in two independent community-based cohorts of elderly. Nephrol Dial Transplant. 2014;29(11):2069-74.

29. Jerkic M, Vojvodic S, Lopez-Novoa JM. The mechanism of increased renal susceptibility to toxic substances in the elderly. Part I. the role of increased vasoconstriction. Int Urol Nephrol. 2001;32(4):539-47.

30. Lindeman RD, Goldman R. Anatomic and physiologic age changes in the kidney. Exp Gerontol. 1986;21(4-5):379-406.

31. Haase-Fielitz A, Haase M, Bellomo R, Calzavacca P, Spura A, Baraki H, Kutschka I, Albert C. Perioperative hemodynamic instability and fluid overload are associated with increasing acute kidney injury severity and worse outcome after cardiac surgery. Blood Purif. 2017:43(4):298-308.

32. Martensson J, Bellomo R. Perioperative renal failure in elderly patients. Curr Opin Anaesthesiol. 2015;28(2):123-30.

33. Muroya Y, He X, Fan L, Wang S, Xu R, Fan F, Roman RJ. Enhanced renal ischemia-reperfusion injury in aging and diabetes. Am J Physiol Ren Physiol. 2018:315(6):F1843-54.

34. Wang X, Bonventre JV, Parrish AR. The aging kidney: increased susceptibility to nephrotoxicity. Int J Mol Sci. 2014;15(9):15358-76.

35. Brienza N, Giglio MT, Marucci M, Fiore T. Does perioperative hemodynamic optimization protect renal function in surgical patients? A meta-analytic study. Crit Care Med. 2009;37(6):2079-90.

\section{Publisher's Note}

Springer Nature remains neutral with regard to jurisdictional claims in published maps and institutional affiliations.

Ready to submit your research? Choose BMC and benefit from:

- fast, convenient online submission

- thorough peer review by experienced researchers in your field

- rapid publication on acceptance

- support for research data, including large and complex data types

- gold Open Access which fosters wider collaboration and increased citations

- maximum visibility for your research: over $100 \mathrm{M}$ website views per year

At $\mathrm{BMC}$, research is always in progress.

Learn more biomedcentral.com/submissions 